\title{
Some physiological consequences of keeping Mytilus edulis in the laboratory
}

\author{
B. L. BAYNE and R. J. Thompson \\ Department of Zoology, University of Leicester; Leicester, England
}

KURZFASSUNG: Einige physiologische Konsequenzen bei der Hälterung von Mytilus edwlis im Laboratorium. Bei Nahrungsmangel und unter Temperaturstreß verringerte sich in den Geweben von Mytilus edulis L. der Gehalt an Kohlehydraten und Proteinen. Diese Substanzverluste sind im Mantelgewebe größer als in den übrigen Geweben. Trotz der Gewichtsreduktion sistiert jedoch die Keimzellbildung nicht. Je stärker der Streß, um so intensiver ist der Abbau von Kohlehydraten und Proteinen, wobei zwischen Kohlehydrat- und Proteinanteil eine proportionale Beziehung erhalten bleibt. Der $\mathrm{O}_{2}$-Verbrauch nahm unter den genannten Versuchsbedingungen $\mathrm{ab}$, die $\mathrm{N}_{2}$-Exkretion stieg an oder ging geringfügig zurück. Das Verhältnis von veratmetem $\mathrm{O}_{2}$ zu ausgeschiedenem $\mathrm{N}_{2}$ nahm bei allen Versuchen $\mathrm{ab}$, und zwar um so stärker, je intensiver der Streß einwirkte. Daraus ist zu schließen, daß Eiweiß zur Energiegewinnung verbraucht wurde. Die Ergebnisse werden im Hinblick auf die Beurteilung des physiologischen Zustandes von Muschelkulturen diskutiert.

\section{INTRODUCTION}

The increasing interest in maintaining populations of lamellibranchs in artificial or semi-artificial conditions for purposes of breeding and cultivation creates a need for more knowledge of the physiological responses to abnormal environments. The conditions that are imposed on a species in hatchery cultivation practice may frequently be characterized by constant high ambient temperatures and relatively low food levels. In so far as these conditions will be sub-lethal, but abnormal, they represent a stress on the animal that may then be reflected in an altered maintenance energy requirement for the animal and consequent physiological responses. Knowledge of these responses should lead to better cultivation practice. Furthermore, it should prove possible to define physiological indices that are both descriptive and predictive of stress, and then to use such indices to characterize natural as well as cultivated populations in order to monitor, for example, the effects of pollution and artificial enrichment of the environment.

This paper is a report of some preliminary experiments designed to follow certain physiological parameters in populations of the common mussel, Mytilus edulis L., kept for long periods in the laboratory. $M$. edulis has already been extensively investigated and is a convenient animal for such experiments because of its ease of culture, its al- 
most ubiquitous distribution and because the invasion of the mantle by the developing gonad facilitates the separate analysis of germinal and somatic tissues.

\section{MATERIALS AND METHODS}

The experiments were carried out in an aquarium with re-circulating seawater. This system carried 3,500 litres of water which was cooled in a reservoir tank, circulated via a flow ultra-violet unit to the specimen tanks and thence through a $2.5 \mathrm{~m}^{3}$ gravel filter bed back to the reservoir tank. Half the total capacity of the system was discarded and replaced with fresh seawater every four months. At regular intervals the following parameters were measured: temperature (by continuous recording); oxygen saturation (with an oxygen electrode); $\mathrm{pH}$, total alkalinity and total nitrate (according to STRICKLANd \& Parsons 1960) and bacterial count (by membrane filtration followed by growth on an agar/yeast-extract medium). Temperature was controlled at $15^{\circ} \pm 1^{\circ} \mathrm{C}$. Chlorinity varied between $18 \%$ and $19.5 \%$ (mean $18.5 \%$ ) and $\mathrm{pH}$ between 7.94 and 8.12 with an overall mean of 8.05 . Oxygen concentration was always within $5 \%$ of full saturation. Nitrate values were high, but relatively constant, varying from 139 to $152 \mu \mathrm{g}$ at $\mathrm{NO}_{3} \mathrm{~N} / \mathrm{l}$. Total alkalinity varied between 2.73 and 3.34 milliequivalent/l. The light regime was $14 \mathrm{~h}$ light/10 h dark, with an average light intensity of 350 lux at the water surface. The total bacterial count was variable, but always low, ranging from 10 to $280 \mathrm{bacteria} / \mathrm{ml}$.

Mytilus edulis L. was collected from a small population at Heacham Beach on the Wash. Animals of uniform lenght were selected, mean $4.50 \pm \mathrm{s}$. d. $0.84 \mathrm{~cm}$. Three "routine cultures" were set up (Tab. 1); (1) from 6th November, 1968 to 20th January, 1969 (75 days); (2) from 3rd February to 28th April, 1969 (84 days); (3) from 6th May to 31 st July, 1969 (86 days). In each of these cultures, 100 animals were placed in a 701 tank with rate of flow $200 \pm 10 \mathrm{ml} / \mathrm{min}$. The test individuals were fed with Tetraselmis suecica (KYLIN) BuTcH., which was grown in monoculture and continuously dosed into the tanks. Cell numbers and particulate protein (PRICE 1965) were measured occasionally. For Table 1 the food levels were estimated as mg dry organic matter $/$ assuming protein to be $45 \%$ of the dry weight of the cells. Concurrently with routine culture 3 a similar tank with $100 \mathrm{M}$. edulis was set up but no food was added and the inflowing water was filtered through a candle filter of $2 \mu$ porosity; this is referred to as "unfed culture 3".

In addition to the routine cultures, two "temperature experiments" were carried out, in which 50 mussels were placed in each of three 41 open trays, with flow rate 100 $\mathrm{ml} / \mathrm{min}$, at (a) $6^{\circ}, 11^{\circ}$ and $16^{\circ} \mathrm{C}$, all $\pm 1^{\circ} \mathrm{C}$, and (b) $10^{\circ}$ and $20^{\circ} \pm 1^{\circ} \mathrm{C}$. These were fed continuously with Tetraselmis suecica. Finally, a "ration experiment" was run in which 30 animals were held in each of two 8.251 polythene buckets, with flow rate $50 \pm$ $10 \mathrm{ml} / \mathrm{min}$. T. suecica was dosed into one bucket ("high ration") at $10^{7}$ cells $/ 1$, and into the other ("low ration") at $10^{6}$ cells $/ 1$.

Mytilus edulis were withdrawn at intervals during the course of these experiments (a) for biochemical analysis (all except temperature experiment 2); (b) for determination of a gonad index and (c) for determination of oxygen consumption and nitrogen 
excretion. For all experiments initial values were determined within two days of sampling the field population. These values, taken together with values from two field samples analysed in March and July, are used as representative of the seasonal trend in the parameters in the natural population, as well as for the initial values in the experiments.

(a) Six Mytilus edulis were taken from the tanks, their length and width measured, and opened by cutting the adductor muscle. They were placed in an oven at $50^{\circ} \mathrm{C}$ for 10 minutes and then weighed (total weight). The flesh was then excised and weighed (flesh weight). Flesh weight as a percentage of total weight was used as an estimate of condition (ANSELL et al. 1964). The mantle was then dissected and the mantle and non-mantle flesh of two animals pooled to provide six units of tissue for analysis. These were homogenised in a Potter-Elvehjem homogeniser and dried to constant weight at $90^{\circ} \mathrm{C}$. Portions were taken from the dried homogenates for determination of nitrogen, carbohydrate and ash.

Total nitrogen was determined by Kjeldahl digestion followed by distillation in a Markham Still, collection in boric acid and back titration with sulphuric acid. Protein values are given as nitrogen $\times 6.25$. Total carbohydrate was determined as glucose equivalents, after homogenising with cold trichloracetic acid (BARNES \& HEATH 1966), by the phenol-sulphuric acid method. Ash was determined after combustion at $450^{\circ} \mathrm{C}$ to constant weight.

(b) Ten Mytilus edulis were taken from the tanks and a piece of mantle tissue examined for determination of the gonad index. The tissue was squashed on a slide and graded into the following stages: (1) mantle is thick but no gametes are observable; (2) mantle is thick and sperm and oocytes are observed in the squash, but the sperm are not active in seawater and the seminal vesicle of the oocyte does not disappear on release into seawater; (3) the gametes are activated on release into seawater, $i$. e. the sperm are active or the oocytes lose the seminal vesicle; (4) the mantle is thin, and no gametes are visible (stage 0 ). The numbers of animals that fall into each category are multiplied by the number of the stage and the sum divided by the number of animals in the sample. This yields an index that ranges from 0 for fully spawned or 'spent' animals, to 3 for ripe animals in the pre-spawning stage (CHIPPERfIELd 1953). This gonad index suffers from not recognising a 'partially spawned' stage (Lubet 1955) in which some, but not all, of the gametes have been released. Such a condition is recognisable, however, by the patchy appearance of the mantle and may be recorded as a partially spawned stage 3 .

(c) A Mytilus edulis was removed from the tank and placed in filtered seawater (candle filter, porosity $0.3 \mu$ ) in a $655 \mathrm{ml}$ glass chamber for $30 \mathrm{~min}$. The water was then gently replaced with freshly filtered water, the chamber sealed and a Beckman macro-oxygen electrode inserted. The chamber was placed on an immersible magnetic stirrer in a water bath; the water was stirred gently and the decline in oxygen tension was recorded for two hours. Oxygen consumption by the animal was calculated from the rate of decline of oxygen tension. At the same time a similar volume of water, without an animal, was held in the water bath as a control. After two hours, two $10 \mathrm{ml} \mathrm{sam-}$ ples were taken from both the experimental and the control chambers and a Kjeldahl digestion carried out overnight until fuming ceased and gentle refluxing occurred. 
The digests were then made up to $98 \mathrm{ml}$ with double-distilled water, $2 \mathrm{ml}$ of a citrate buffer of $\mathrm{pH} 4.8$ added, and the solution brought to $\mathrm{pH} 4.75 \pm 0.05$ with $40 \%$ $\mathrm{NaOH}$. Ammonia was then estimated by the method of Newell (1967).

These experiments were carried out in triplicate. They afforded a simultaneous estimate of oxygen consumption and nitrogen excretion. We consider that the period of measurement, i. e. $2 \mathrm{~h}$, is possibly too short for very reliable estimates of excretion rates; there was considerable variation in the final values for excretion. However, the results are considered suitable for identifying trends in excretion during the course of the culture experiments.

Whenever animals were removed from a tank for measurement, they were replaced by others. The replacements were marked in order to distinguish them from experimental animals in subsequent sampling.

\section{RESULTS}

\section{Condition and gonad index}

The condition index and the gonad index for routine cultures 1,2 and 3 are plotted in Figure 1. In all cultures the condition index declined. In culture 2 the decline was sharp during the first 20 days. The condition of the unfed individuals in culture 3 was consistently lower than the condition of the fed individuals. In routine cultures 1 and 2 the gonad index increased slightly, whereas in culture 3 it declined, from 2.85 to 1.50 for unfed animals and from 2.85 to 1.70 for fed animals. There was a decline in

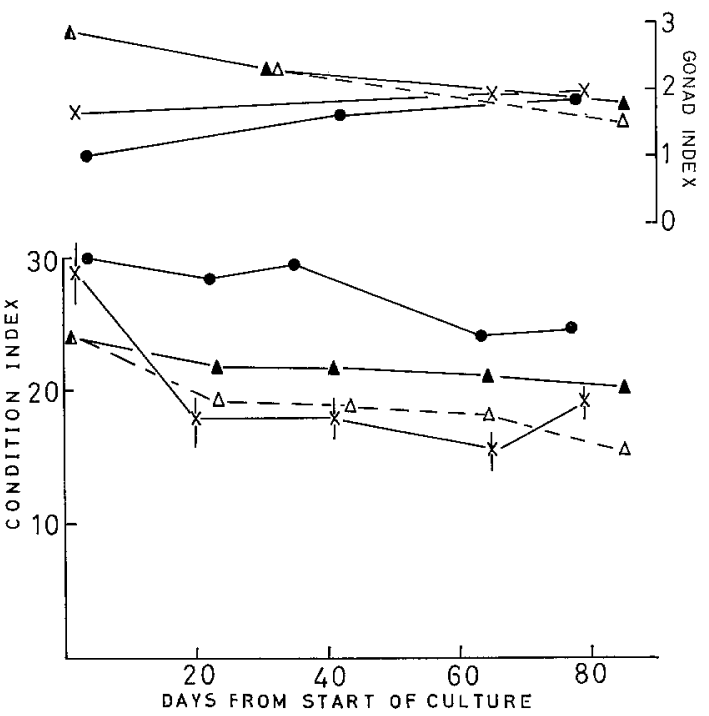

Fig. 1: Gonad index and condition index of Mytilus edulis. Filled circles: culture 1; crosses: culture 2 (vertical bars indicate total ranges); filled triangles: culture 3 fed individuals, open triangles: unfed individuals 
mantle dry weight in all experiments. Thus, in experiments initiated in November and February (when the gametes were not yet ripe) further development of the gametes proceeded even though the general condition of the body declined. In culture 3, started in May when the gametes had already matured, the decline in the general condition index was accompanied by a recession of the gonads. In the ration experiment, however, which was held at the same time as culture 3 , but in which food levels were higher, the gonad index recessed rather less (to 2.2 after 60 days.)

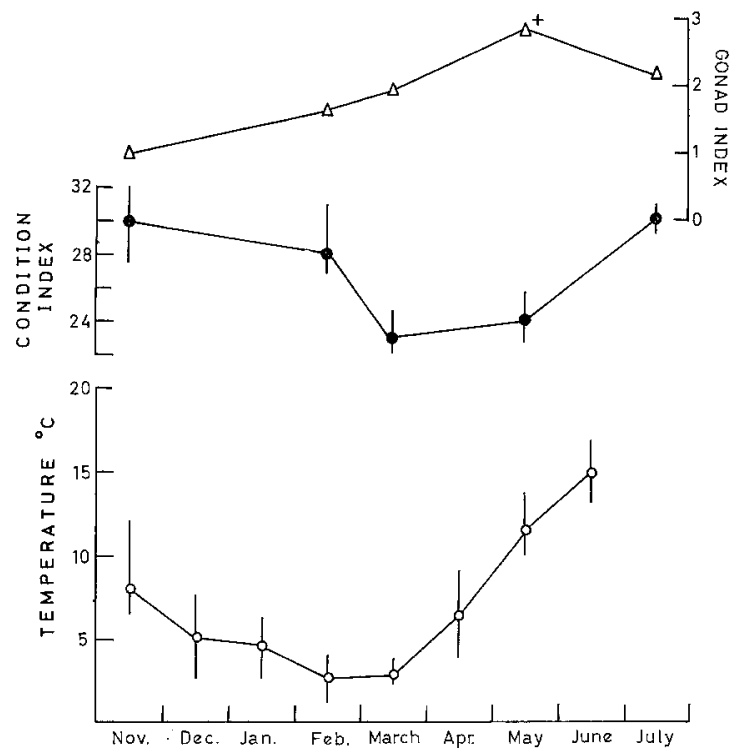

Fig. 2: Mytilus edulis. Seasonal trends in gonad index (open triangles) and condition index (filled circles). Sea-water temperatures at Brancaster (courtesy Lowestoft Fisheries Laboratory) are indicated by open circles, evidence of partial spawning in May by a cross

In Figure 2 five values for the condition and gonad indices, as measured within two days of sampling the field population, are plotted. The data are insufficient to describe a seasonal trend in detail, but it is apparent that, in the field population also, a decline in the condition index during the winter and spring accompanied an increase in the gonad index. BAIRD (1966) recorded a similar situation in a mussel population in North Wales. Also plotted in Figure 2 are the monthly mean values for the inshore water temperatures near to the mussel sampling site at Brancaster, (data kindly supplied by the Lowestoft Fisheries Laboratory). The decline in condition paralleled a drop in the water temperature, but recovery of condition lagged behind the temperature rise from March to June. Partial spawning was recorded for the field sample taken in early May.

The first temperature experiment was carried out during part of the period of routine culture 2 ; the results (Fig. 3 ) showed that the decline in condition was greater at $16^{\circ} \mathrm{C}$ than at $6^{\circ} \mathrm{C}$, and that only at $16^{\circ} \mathrm{C}$ did the gonad index fall significantly. Similarly, in the second temperature experiment, which was run concurrently with routine 
culture 3, the gonad index declined markedly at $20^{\circ} \mathrm{C}$ (2.85 to 1.84$)$ but very little at $10^{\circ} \mathrm{C}(2.85$ to 2.71$)$. These results are in agreement with descriptions by LoosanofF \& Davis (1951) and BAYNe (1965) of techniques for delaying the release of gametes by bivalves. These techniques include holding ripe individuals (with a gonad index approaching 3) at low temperatures $\left(5^{0}-6^{\circ} \mathrm{C}\right.$ for Mytilus edulis) with some food, for periods up to 12 months, during which time the gonads do not recess and the animals remain capable of spawning when stimulated.
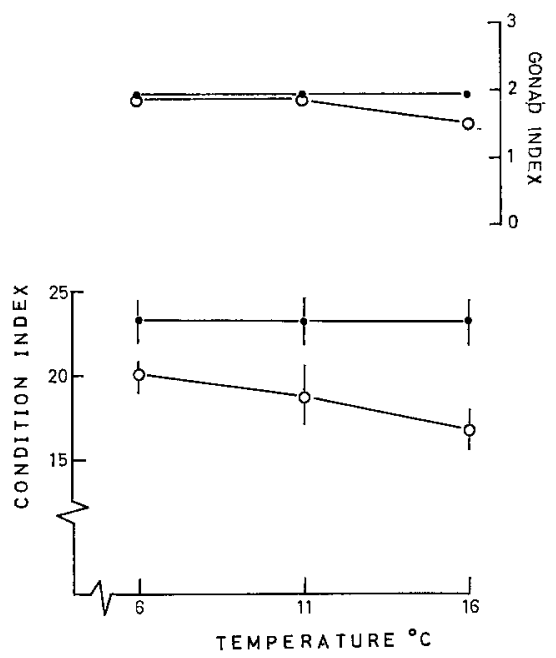

Fig. 3: Mytilus edulis. Gonad index and condition index temperature experiment 1. Filled circles: after 1 day of culture; open circles: after 48 days of culture

We therefore suggest that Mytilus edulis may continue normal development of the gametes whilst the body condition declines due to stresses in the environment, as long as the gametes themselves are not yet ripe. After the maturation of the gametes, however, the animals that are under a sub-lethal temperature or nutritive stress are unable to maintain the gametes in a ripe condition and a recession of the gonad occurs. Maintenance of mature gamete development is possible when the temperature/nutritive stress is reduced to a minimum.

\section{Biochemical composition}

Due to the narrow length range of animals used in these experiments, the results may be referred to a standard animal of $4.6 \mathrm{~cm}$ maximum shell length and $2.3 \mathrm{~cm}$ maximum shell width. The results of the body analyses in different experiments may then be compared as changes in dry weight, weight of carbohydrate and weight of protein.

The total dry weights of animals in routine cultures 1,2 and 3 and in the ration experiment are shown in Figure 4. In all experiments conducted at $15^{\circ} \mathrm{C}$ there was a decline in dry weight; the overall decline was $32 \%$ in culture $1,33.5 \%$ in culture 2 , 
$40.5 \%$ in culture 3 (fed animals), and $57 \%$ in culture 3 (unfed animals). These differences may be ascribed to variations in the culture conditions (Table 1) and to the degree of deviation from natural conditions imposed by laboratcry conditions i. e. the degree of stress imposed by the conditions of culture. The total weight of ash did not change significantly during the experiments, although ash expressed as percentage of dry weight did increase during the course of the cultures.

The overall drop in the dry weights of animals in these cultures supports the view that the maintenance energy requirement of the animals was not being met. It also

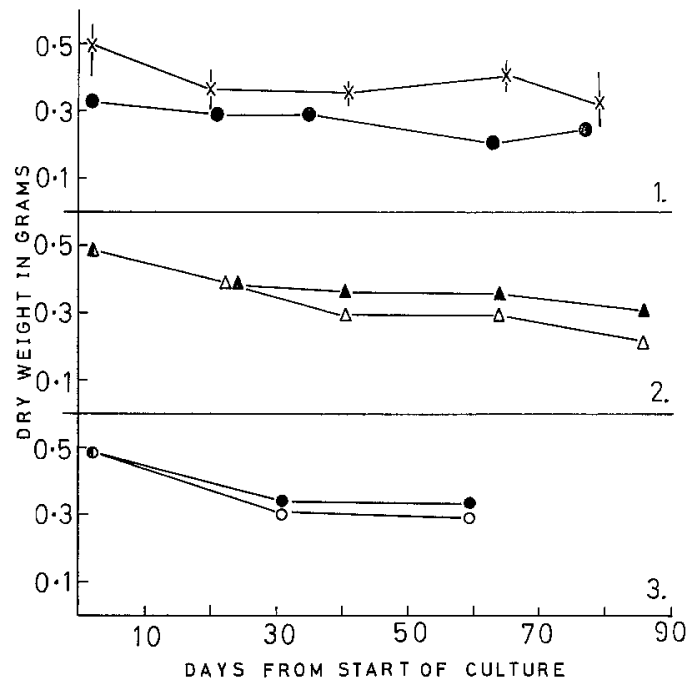

Fig. 4: Dry weight of Mytilus edulis. (1): Culture 1 (filled circles), culture 2 (crosses; vertical bars indicate total ranges). (2): Culture $3 \mathrm{fed}$ individuals (filled triangles), unfed individuals (open triangles). (3): High ration experiment (filled circles), low ration experiment (open circles)

seems likely that the stress imposed by the culture conditions further increased the natural maintenance requirement. This is supported by the first temperature experiment in which, after 48 days, animals at $6^{\circ} \mathrm{C}$ had increased in mean dry weight from 0.34 to $0.38 \mathrm{~g}$, animals at $11^{\circ} \mathrm{C}$ had shown no change in total dry weight, whereas animals at $16^{\circ} \mathrm{C}$ had declined to $0.19 \mathrm{~g}$ mean dry weight. Also, results from the two main experiments in which ration was varied (i. e. in routine culture 3 and the ration experiment) showed, as expected, that animals at the lower of two food levels declined in dry weight to a greater extent than animals at the higher level.

The results of the analyses for carbohydrate and protein in the mantle and nonmantle tissues are summarised in Tables 2 and 3 for routine cultures 1, 2 and 3, and the ration experiment. The values for culture 2 are plotted as percentages of the initial values in Figure 5, and the data from the ration experiment as percentages of dry weight in Figure 6. The initial values, which are taken as representative of the seasonal variation in the field population, indicate that animals sampled in November had more 
carbohydrate and less protein in both mantle and nonmantle than did animals taken in February and May. These differences are interpreted as reflecting the gradual maturation of the gametes during the winter and spring (Daniel 1921, 1922, Williams 1969). In all the cultures, both carbohydrate and protein declined, the decline being greater in culture 3 than in cultures 1 and 2. Carbohydrate and protein decreased relatively more in the mantle than in the non-mantle tissues. Finally, the results indicate a more rapid loss of carbohydrate than protein.

\section{Table 1}

Mytilus edulis. Details of the conditions of culture in the different experiments

\begin{tabular}{|c|c|c|c|c|c|c|c|}
\hline Experiment & Dates & $\begin{array}{l}\text { Duration } \\
\text { (days) }\end{array}$ & $\begin{array}{c}\text { Mean } \\
\text { number } \\
\text { food cells } \\
\text { (per ml) }\end{array}$ & $\begin{array}{c}\text { Water } \\
\text { available } \\
\text { per animal } \\
\text { (1/day) }\end{array}$ & $\begin{array}{c}\text { Ration } \\
\text { (mg or- } \\
\text { ganic mat- } \\
\text { ter/ani- } \\
\text { mal/day) }\end{array}$ & $\begin{array}{c}\text { Ambient } \\
\text { tempera- } \\
\text { ture at } \\
\text { sample } \\
\text { date } \\
\left({ }^{\circ} \mathrm{C}\right)\end{array}$ & $\begin{array}{l}\text { Experi- } \\
\text { enced tem- } \\
\text { perature } \\
\text { rise } \\
\left(\mathrm{C}^{0}\right)\end{array}$ \\
\hline Routine 1 & $\begin{array}{l}\text { Nov.- } \\
\text { Jan. }\end{array}$ & 75 & 600 & 2.9 & 0.33 & 12.5 & 2.5 \\
\hline Routine 2 & $\begin{array}{l}\text { Feb.- } \\
\text { April }\end{array}$ & 85 & 700 & 2.9 & 0.32 & 5.0 & 10.0 \\
\hline $\begin{array}{l}\text { Routine } 3 \\
\text { (1) fed } \\
\text { (2) unfed }\end{array}$ & $\begin{array}{l}\text { May- } \\
\text { July }\end{array}$ & $\begin{array}{l}85 \\
85 \\
\end{array}$ & $\begin{array}{l}1,200 \\
200 \%\end{array}$ & $\begin{array}{l}2.9 \\
2.9 \\
\end{array}$ & $\begin{array}{l}0.55 \\
0.03 \\
\end{array}$ & $\begin{array}{l}10.0 \\
10.0 \\
\end{array}$ & $\begin{array}{l}5.0 \\
5.0 \\
\end{array}$ \\
\hline $\begin{array}{l}\text { Temper- } \\
\text { ature } 1\end{array}$ & $\begin{array}{l}\text { March- } \\
\text { April }\end{array}$ & 48 & 950 & 2.0 & 0.48 & 2.5 & $\begin{array}{r}3.5,8.5 \\
8 \times 13.5 \\
\end{array}$ \\
\hline $\begin{array}{l}\text { Temper- } \\
\text { ature } 2\end{array}$ & $\begin{array}{l}\text { May- } \\
\text { July }\end{array}$ & 85 & 750 & 2.9 & 0.30 & 10.0 & 10.0 \\
\hline $\begin{array}{l}\text { Ration } \\
\text { (1) high } \\
\text { (2) low }\end{array}$ & $\begin{array}{l}\text { May- } \\
\text { July }\end{array}$ & $\begin{array}{l}60 \\
60\end{array}$ & $\begin{array}{r}10,000 \\
1,000\end{array}$ & $\begin{array}{l}2.4 \\
2.4\end{array}$ & $\begin{array}{l}5.00 \\
0.50\end{array}$ & $\begin{array}{l}10.0 \\
10.0\end{array}$ & $\begin{array}{l}5.0 \\
5.0\end{array}$ \\
\hline
\end{tabular}

These results are consistent with the view that the mantle serves both as a site for the storage of reserve materials and for the production and maturation of gametes. In culture 1 , in which the gonad index increased, the decline in mantle protein was slight. The gonad index in culture 2 was maintained and there was a significant decline in mantle protein. In culture 3 (fed animals) there was a marked decline in the gonad index, and here the protein reserves, especially those in the mantle, were rapidly utilised.

It is clear that there is a complex relationship between the development of the gametes and the readiness with which the carbohydrate and protein reserves of the body are utilised when the animals are stressed. The data presented here emphasises a conclusion already drawn, that Mytilus edulis may conserve and encourage the production of gametes at the expense of other body tissues, at a time when the gametes are not yet ripe. After maturation of the gametes, utilisation of materials from the mantle occurs more readily and the gametes are soon recessed. 


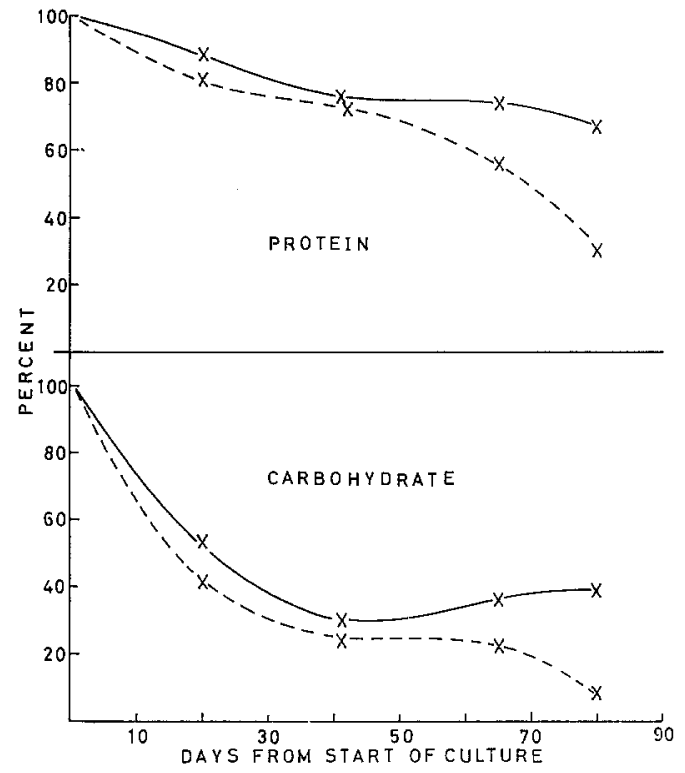

Fig. 5: Mytilus edulis. Protein and carbohydrate expressed as percentages of initial values in mantle (broken line) and total flesh (solid line) in culture 2

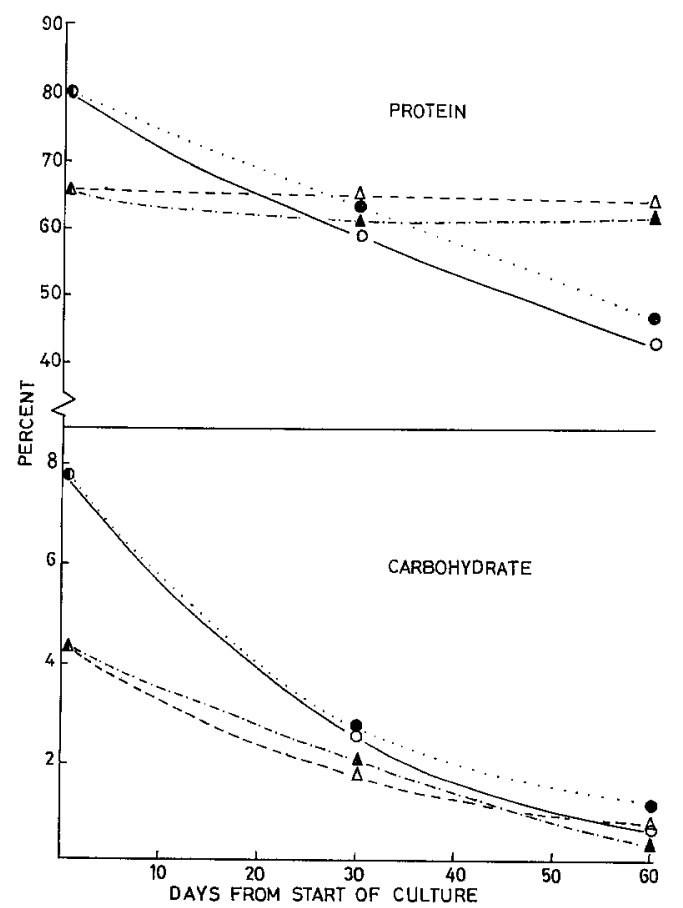

Fig. 6: Mytilus edulis. Protein and carbohydrate expressed as percentages of dry weight. High ration individuals: mantle (open circles), total flesh (open triangles); low ration individuals: mantle (filled circles), total flesh (filled triangles) 


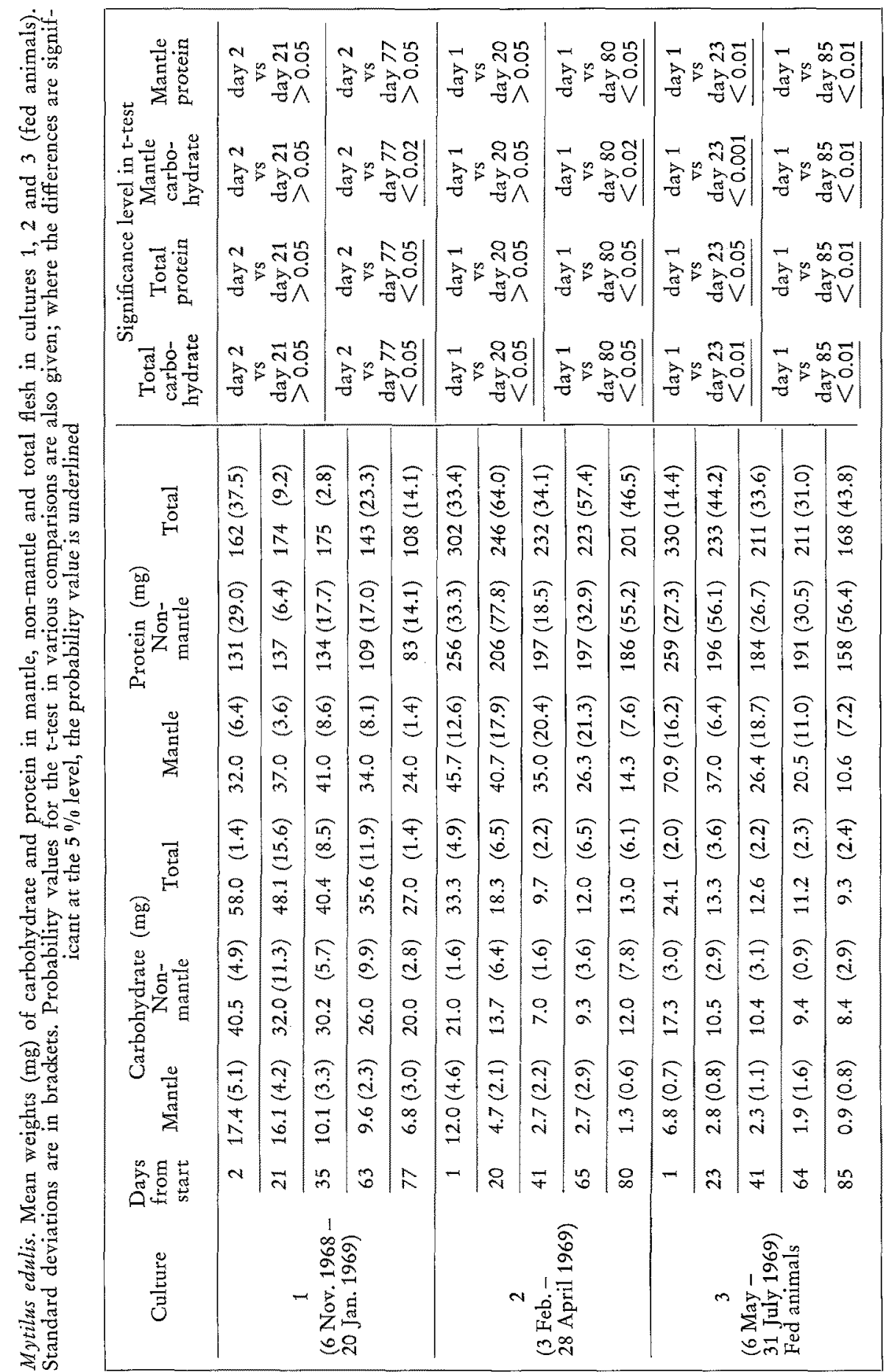




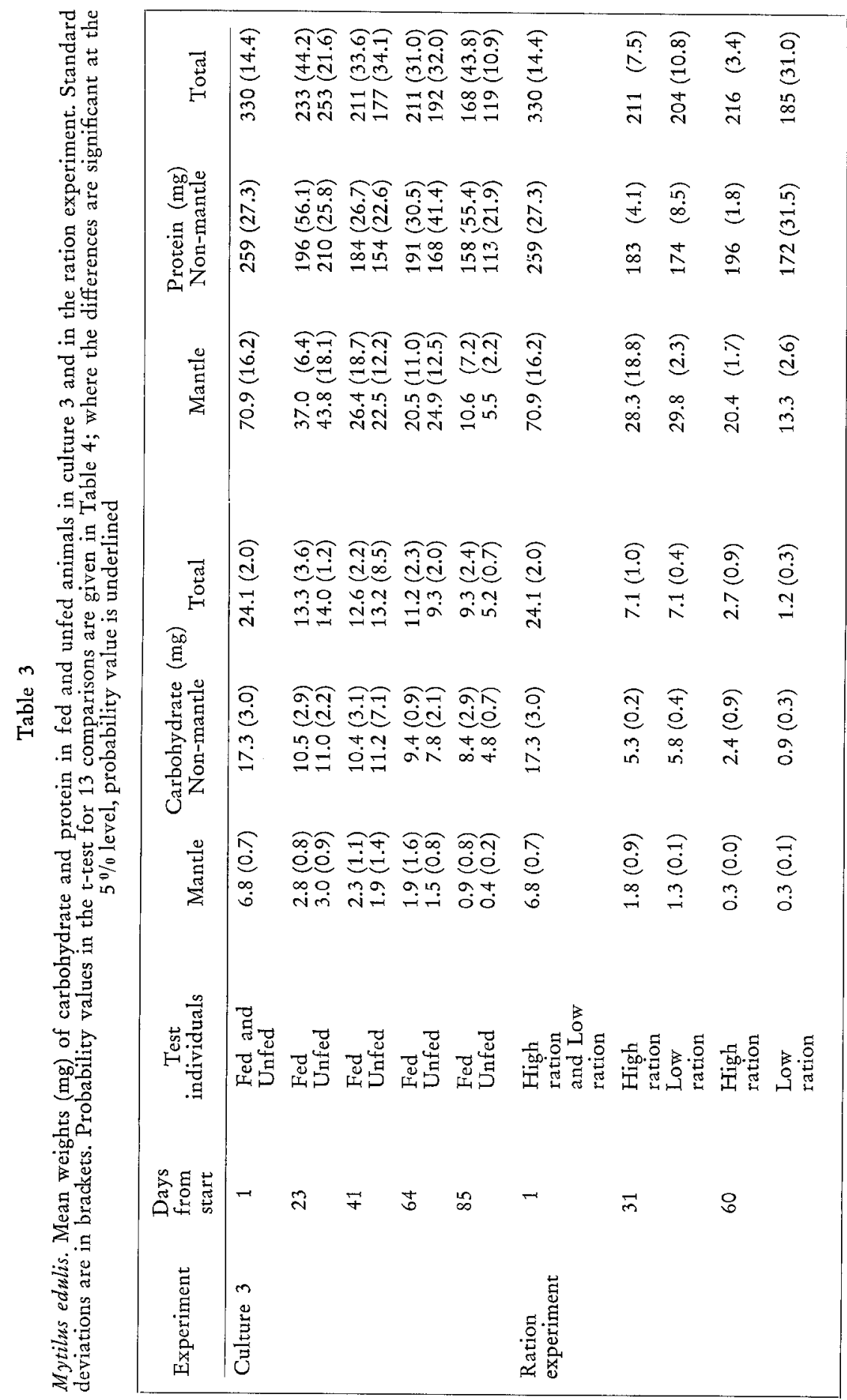




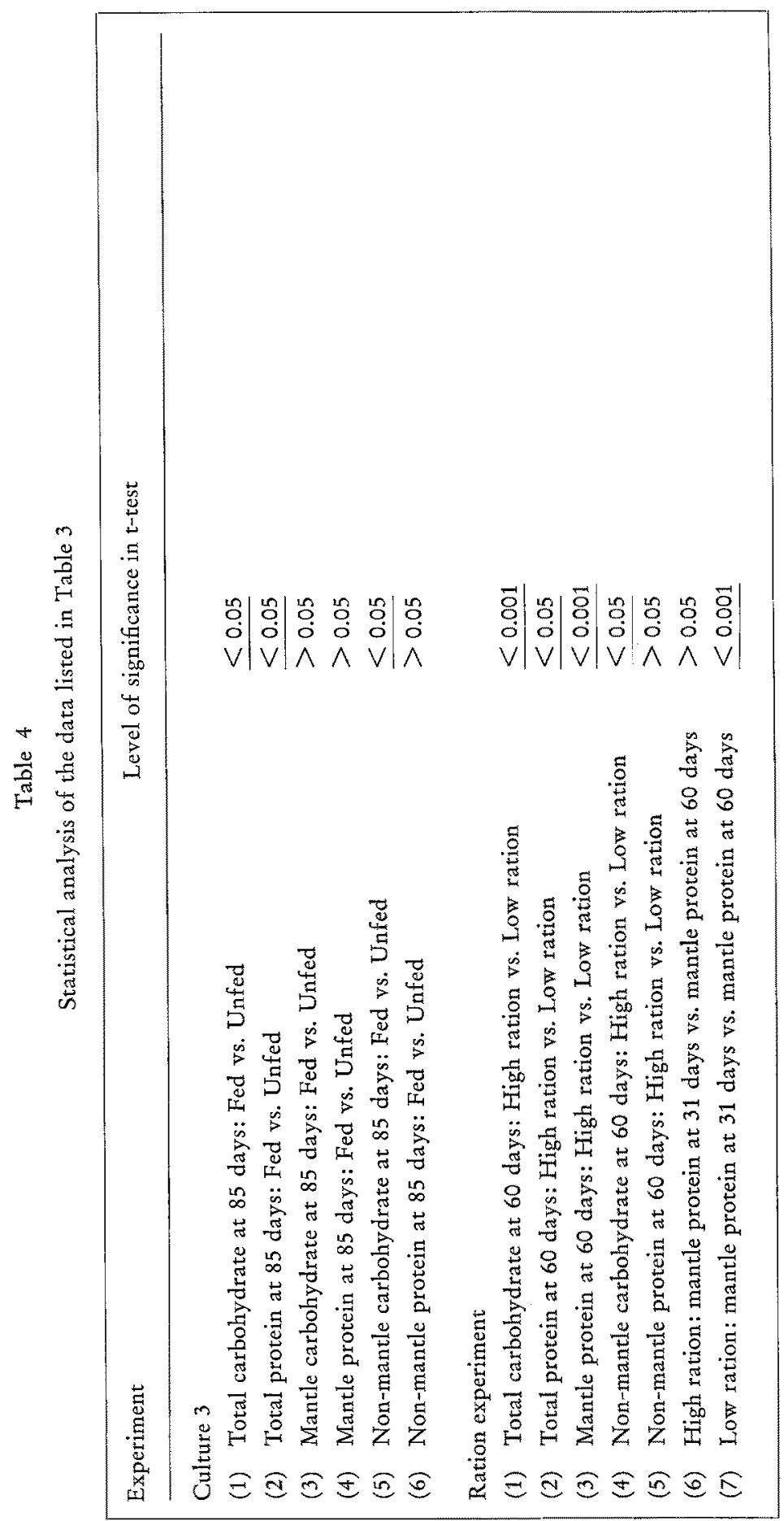


In November 1968, when routine culture 1 was started, the seawater temperature near the sampling site was $12.5^{\circ} \mathrm{C}$; the test individuals were therefore submitted to a temperature rise of $2.5 \mathrm{C}^{0}$ on being brought into the laboratory. In February (routine culture 2), the seawater temperature was $5.0^{\circ} \mathrm{C}$ and the temperature rise therefore $10.0 \mathrm{C}^{0}$. For temperature experiment 1 animals were brought in from the field population in March and submitted to temperature increases of $3.5 \mathrm{C}^{0}$ (from $2.5^{\circ} \mathrm{C}$ in the field to $6.0^{\circ} \mathrm{C}$ in the laboratory), $8.5 \mathrm{C}^{0}$ (to $11^{\circ} \mathrm{C}$ ) and $13.5 \mathrm{C}^{0}$ (to $16^{\circ} \mathrm{C}$ ) in order to investigate the effects of such temperature changes. Figure 7 represents

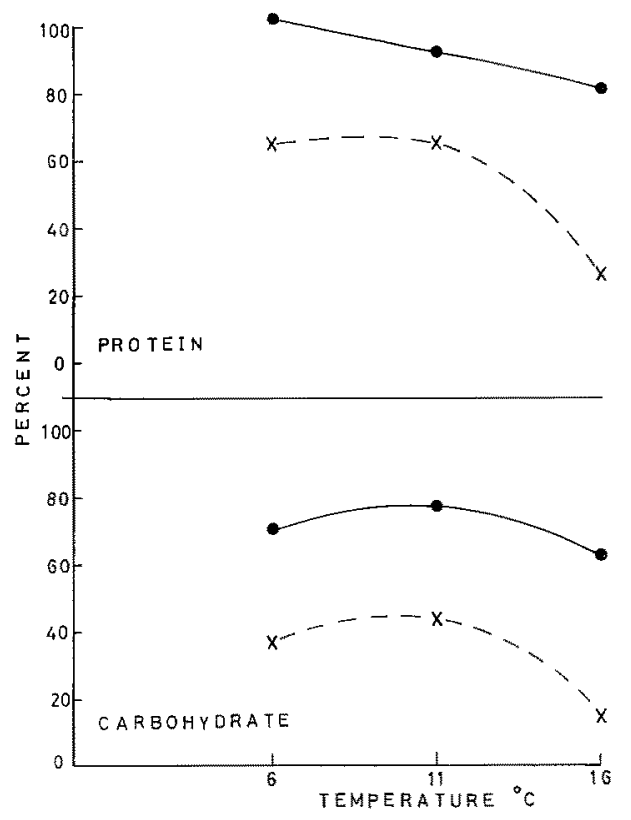

Fig. 7: Mytilus edulis. Protein and carbohydrate expressed as percentage changes after 48 days in temperature experiment 1. Mantle (crosses), total flesh (filled circles)

the percentage changes in carbohydrate and protein for total flesh and for mantle tissue after 48 days. Total protein did not alter significantly at $6^{\circ}$ and $11^{\circ} \mathrm{C}$, but declined by $20 \%$ at $16^{\circ} \mathrm{C}$; mantle protein declined in all cases, but most extensively at $16^{\circ} \mathrm{C}$. Similarly, the total and mantle carbohydrate declined at all three temperatures but the greatest decrease occurred at $16^{\circ} \mathrm{C}$. More experiments on both the short-term and long-term effects of temperature changes are necessary, but the results from this one experiment suggest that the overall deviation from the natural temperature regime represented an important stressor in these experiments. This might partly explain the slightly better ability of the test individuals in routine culture 1 to adapt to the laboratory conditions. In this culture there was a nutrient deficiency but only a slight temperature stress, whereas in culture 2 both the temperature and the ration imposed significant stress on the animals.

The effects of ration were investigated further in routine culture 3 and in the ra- 
tion experiment (Tables 3,4). There was a characteristic decline in carbohydrate and protein in all cultures. However, after 85 days in culture 3 , the fed and unfed animals differed significantly only in non-mantle and total carbohydrate and in total protein; neither mantle protein nor mantle carbohydrate showed a significant difference between fed and unfed animals. It appears that carbohydrate and protein reserves in the mantle were equally utilised by both fed and unfed test individuals; the greater requirement for reserve energy in the unfed animals was met, primarily, from the carbohydrate of the non-mantle tissues. Similarly, in the ration experiment, there was a significant decline in total carbohydrate and total protein after 60 days, with a greater loss in the low-ration animals (Table 3 ). In this experiment, there was no significant difference in mantle carbohydrate between high-ration and low-ration animals after 60 days, but a marked difference in the carbohydrate of the non-mantle. Mantle protein declined significantly more in low-ration animals but there was no significant difference in non-mantle protein.

Table 5

Mytilus edulis. Total weight loss, and loss of carbohydrate and protein, in cultures 1, 2 and 3, and in the ration experiment

\begin{tabular}{|c|c|c|c|c|c|c|c|c|}
\hline Culture & Days & $\begin{array}{l}\text { Total weigh } \\
\text { loss (mg) }\end{array}$ & $\begin{array}{c}\text { Carbo } \\
\mathrm{mg}\end{array}$ & $\begin{array}{l}y d r a t e ~ l o s s \\
\% \% \text { of total }\end{array}$ & $\begin{array}{l}\text { Pro } \\
\mathrm{mg}\end{array}$ & $\begin{array}{l}\text { tein loss } \\
0 \% \text { of total }\end{array}$ & $\begin{array}{c}\text { Unacco } \\
\text { mg }\end{array}$ & $\begin{array}{l}\text { unted loss } \\
\text { ' of total }\end{array}$ \\
\hline Routine 1 & 75 & 81 & 23.0 & 28.4 & 31 & 38.3 & 27.0 & 33.3 \\
\hline Routine 2 & 80 & 165 & 20.0 & 12.1 & 101 & 61.2 & 44.0 & 26.7 \\
\hline $\begin{array}{l}\text { Routine 3: } \\
\text { fed } \\
\text { unfed }\end{array}$ & $\begin{array}{l}85 \\
85\end{array}$ & $\begin{array}{l}196 \\
276\end{array}$ & $\begin{array}{l}14.8 \\
18.8\end{array}$ & $\begin{array}{l}7.5 \\
6.8\end{array}$ & $\begin{array}{l}161 \\
212\end{array}$ & $\begin{array}{l}82.1 \\
76.8\end{array}$ & $\begin{array}{l}20.2 \\
45.2\end{array}$ & $\begin{array}{l}10.4 \\
16.4\end{array}$ \\
\hline $\begin{array}{c}\text { Ration: } \\
\text { high } \\
\text { low }\end{array}$ & $\begin{array}{l}60 \\
60\end{array}$ & $\begin{array}{l}130 \\
173\end{array}$ & $\begin{array}{l}19.3 \\
22.6\end{array}$ & $\begin{array}{l}14.8 \\
13.1\end{array}$ & $\begin{array}{l}113 \\
143\end{array}$ & $\begin{array}{l}87.1 \\
82.7\end{array}$ & $\begin{array}{l}0 \\
7.4\end{array}$ & $\begin{array}{l}0 \\
4.2\end{array}$ \\
\hline
\end{tabular}

In Table 5 the weights of carbohydrate and protein lost are listed as percentages of the observed overall dry weight losses. The values indicate a greater utilisation of carbohydrate in test individuals sampled in May than in animals sampled in November; a change that reflects the increasing amount of protein in the body from winter to summer.

The balance between carbohydrates and proteins in the tissues may be expressed as the carbohydrate: protein $r a t i o b y$ weight in a standard test individual. This ratio refers carbohydrate to unit weight of protein. C:P curves for animals in the routine cultures 1,2 and 3, and for temperature experiment 1 and the ration experiment are presented in Figures 8, 9 and 10. These curves illustrate the early loss of carbohydrate in the total flesh, and the rapid decline of carbohydrate in the mantle, followed by the establishment of an equilibrium between the loss of carbohydrate and protein. In culture 3 the decline in the C:P ratio was not as marked as in cultures 1 and 2 due to the earlier utilisation of protein (see also Table 2). In the temperature experiment, the C:P ratio for both mantle and total flesh declined, but the rate of change was similar at all three temperatures; although the amount of both materials used was 
greater at $16^{\circ} \mathrm{C}$. Similarly, in the ration experiments there was a characteristic overall decline in the C:P values, but no great differences between animals at different ration levels. Routine culture 3 and the ration experiment used animals sampled at the same time from the same population. In the ration experiment, however, the C:P values declined well below the values for culture 3 . This is associated with the maintenance of a high gonad index by the animals in the ration-experiment. In this experiment the gonad index declined after 60 days from 2.8 to 2.2 , in both high-ration and low-ration animals, in contrast to a decline from 2.8 to 1.7 and 1.5 for the fed and

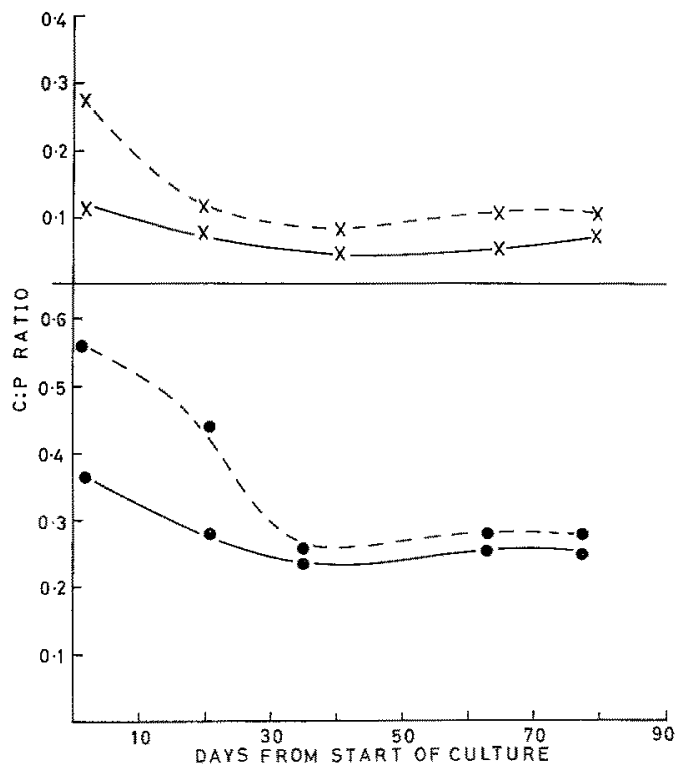

Fig. 8: Mytilus edulis. Ratio carbohydrate: protein. Culture 1: mantle (filled circles, dotted line), total flesh (filled circles, solid line). Culture 2: mantle (crosses, dotted line), total flesh (crosses, solid line)

unfed test individuals of culture 3. Furthermore, this difference may be ascribed to a difference in food levels in the two experiments. In the ration experiment the food levels are estimated to have been 5.0 and $0.5 \mathrm{mg}$ organic matter/animal/day; in culture 3 the levels were 0.55 and $0.03 \mathrm{mg}$ organic matter/animal/day. In the ration experiment, therefore, in spite of utilisation of carbohydrate and protein in the body tissues, the gonad was only slightly recessed. Low-ration individuals utilised more of their body reserves than individuals on high ration but both the degree of recession of the gonad and the C:P ratio were controlled to similar values by both groups of animals. The differences between the C:P values in the two experiments remain somewhat anomalous. Apart from the food levels, other conditions varied slightly between the two experiments, however we can offer no explanation at present for the differences in C:P ratio and gonad index between, for example, the fed animals of culture 3 and the low ration animals in the ration experiment. 
An indication of the degree to which the changes in the C:P ratios in the culture experiments differed from the presumed seasonal trend is given in Figure 11. It appears that the changes in culture 2 closely followed the seasonal change. In culture 1 the early decline in C:P ratio reflected the seasonal decline, but the recovery after 55 days, due to a decline in protein between 35 and 77 days, represented a divergence from the

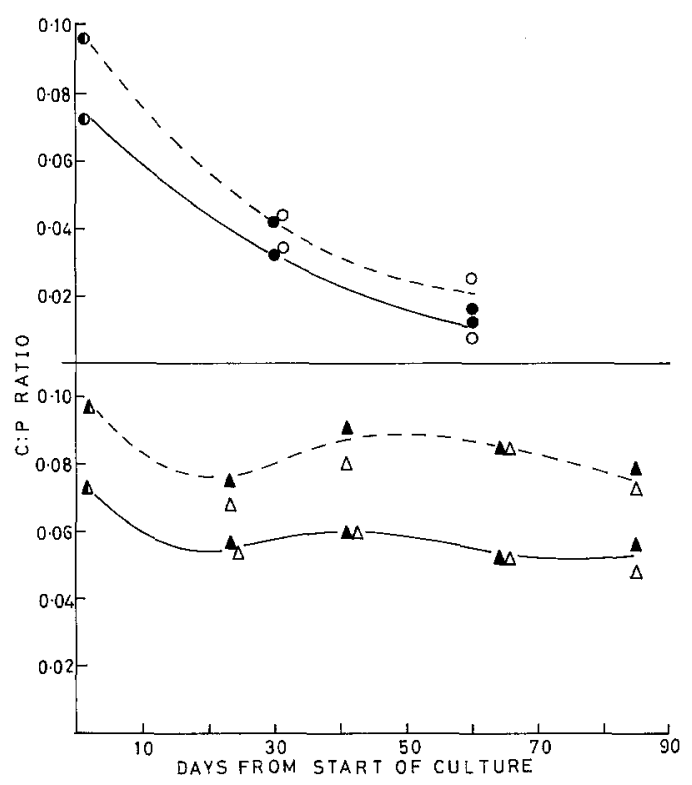

Fig. 9: Mytilus edulis. Ratio carbohydrate: protein. Culture 3: fed (filled triangles) and unfed (open triangles) individuals; mantle (dotted line), total flesh (solid line). Ration experiment: high ration (filled circles), low ration (open circles) for mantle (dotted line) and total flesh (solid line)

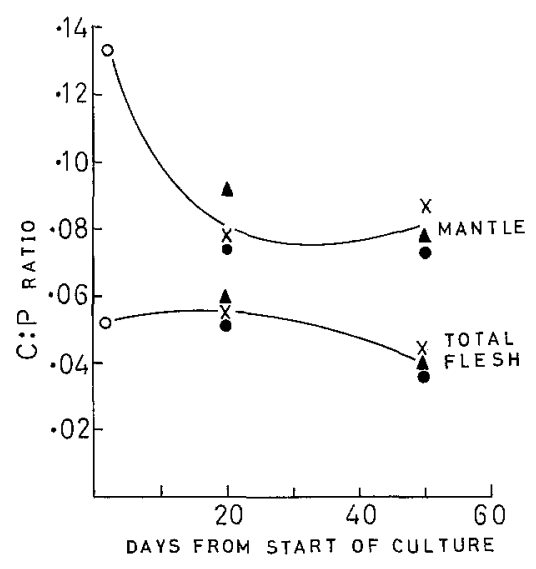

Fig. 10: Mytilus edulis. Ratio carbohydrate: protein. Temperature experiment 1: $6^{\circ} \mathrm{C}$ (filled circles), $11^{\circ} \mathrm{C}$ (crosses), $16^{\circ} \mathrm{C}$ (filled triangles) for mantle and total flesh 
natural trend. Culture 3 showed divergence from the seasonal pattern throughout; this may be due in part to the fact that these animals did not spawn in the laboratory. The field population spawned in May to June, resulting in a sharp increase in the C:P ratio.

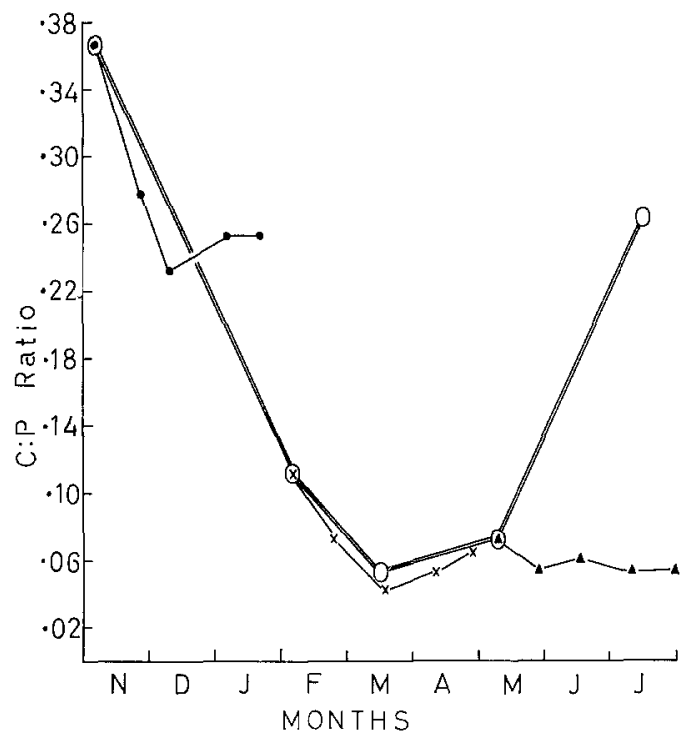

Fig. 11: Mytilus edulis. Seasonal trend in the ratio carbohydrate: protein (large open circles with double lines). Superimposed are data for culture 1 (filled circles), culture 2 (crosses), culture 3 fed individuals (filled triangles)

It appears, therefore, that under the conditions of nutritive and temperature stress represented in these experiments, Mytilus edulis rapidly mobilised reserves of carbohydrate from the mantle to meet the energy requirement. As the stress continued, proteins were also utilised and reserves of both carbohydrate and protein in the nonmantle tissues called upon. With one exception, animals with similar initial levels of reserves utilised these in similar proportion although the absolute level of utilisation was higher the greater the degree of stress. In autumn and winter, the changes in balance, but not in absolute quantities, of carbohydrate and protein in the body were similar in the laboratory individuals to the changes occurring in the field population. In the summer, this similarity was not maintained, due to a failure to spawn by the laboratory population.

\section{Oxygen consumption and nitrogen excretion}

The values of oxygen consumption and nitrogen excretion for the five "field samples" are plotted in Figure 12. These values were determined after 10 to 14 days in the laboratory and are taken to represent rates for animals acclimated to $15^{\circ} \mathrm{C}$. Both show a decline in the weight-specific metabolic rate from a maximum in winter to a mini- 
mum in summer, followed by a rise in late summer and autumn. A similar seasonal trend in oxygen consumption has been described by BRUCE (1926) and KRÜGER (1960).

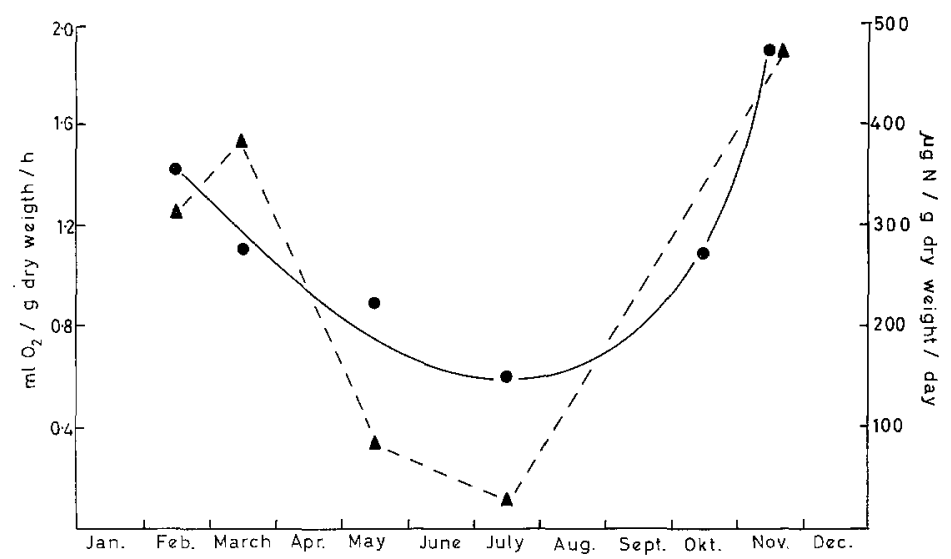

Fig. 12: Mytilus edulis. Seasonal trend in oxygen consumption (filled circles) and nitrogen excretion (filled triangles)

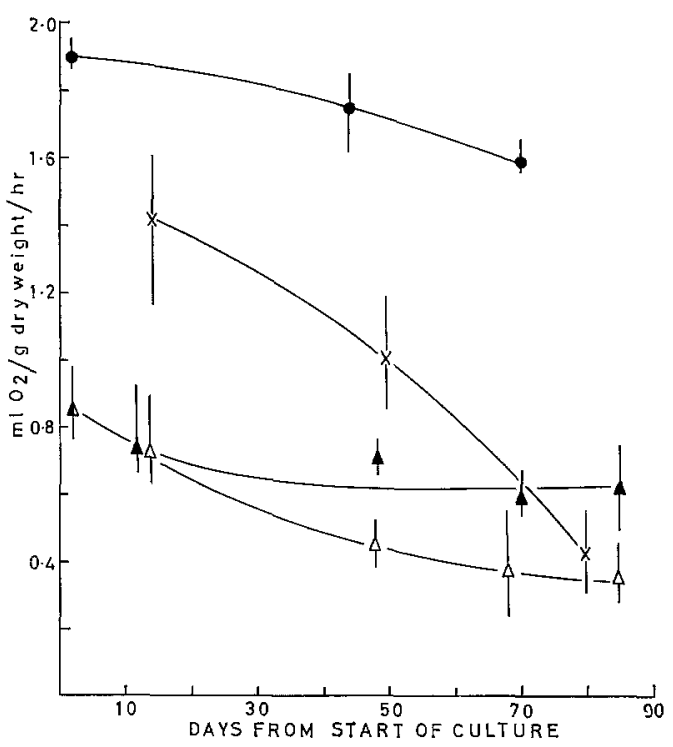

Fig. 13: Mytilus edulis. Weight specific oxygen consumption. Culture 1 (filled circles), culture 2 (crosses), culture 3 fed individuals (filled triangles), culture 3 unfed individuals (open triangles). Vertical bars indicate total ranges

In the culture experiments oxygen consumption declined, whether expressed as dry weight-specific consumption (Fig. 13) or as consumption per individual. In culture 3 the decline in oxygen consumption by unfed animals was greater than for fed 
animals. Such depression of the metabolism during starvation or periods of low ration has been recorded for other invertebrates (e. g. BARNes et al. 1963).

The course of nitrogen excretion was different in the various cultures. When considered as $\mu \mathrm{g} \mathrm{N}$ per individual, excretion in cultures 1 and 2 was rather constant (culture 1: $143 \pm 20 \mu \mathrm{g} \mathrm{N} /$ day; culture 2: $105 \pm 50 \mu \mathrm{g} \mathrm{N} /$ day). In culture 3 there was an overall rise, from 40-55 $\mu \mathrm{g} \mathrm{N} /$ day by fed animals and from 40-102 $\mu \mathrm{g} N /$ day by unfed animals. The values are plotted as weight-specific excretion rates in Figure 14. They show an overall increase in cultures 1 and 3 and a slight decrease in culture 2 .

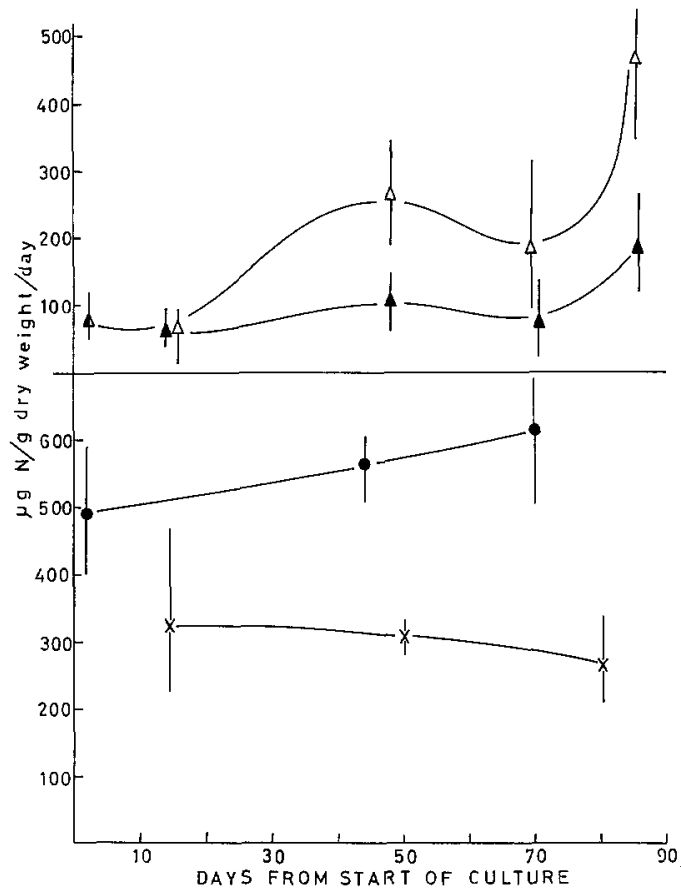

Fig. 14: Mytilus edulis. Weight specific nitrogen excretion. Culture 1 (filled circles), culture 2 (crosses), culture 3 fed individuals (filled triangles), culture 3 unfed individuals (open triangles). Vertical bars indicate total ranges

CORNER \& COWEY (1968) have discussed the usefulness of the ratio oxygen consumed:nitrogen excreted (by atomic equivalents) as an indication of the substrate oxidised by an animal. A low value for this ratio indicates that mainly protein is being utilised, whereas high values indicate the catabolism of carbohydrate or fat. If the amount of protein utilised is the same in two cases, but in one the energy substrate is predominantly fat and in the other predominantly carbohydrate, the former will have a higher $O: N$ value than the latter, due to the higher requirement for oxygen in the catabolism of unit fat than of unit carbohydrate.

Values for the O:N ratio from our data are plotted in Figure 15. In all cultures there was an overall decline in the ratio indicating an increasing use of protein rela- 
tive to carbohydrate and fat. However, these values were all very much higher than have been recorded for planktonic animals (CoRNer \& CowEY 1968), suggesting that relatively less protein is normally utilised by the benthic Mytilus edulis. Apparently, fat and carbohydrate are the substrates normally catabolised, although, in response to the stresses imposed in these experiments, protein substrates were utilised, and this was reflected in the decreasing $\mathrm{O}: \mathrm{N}$ ratios.

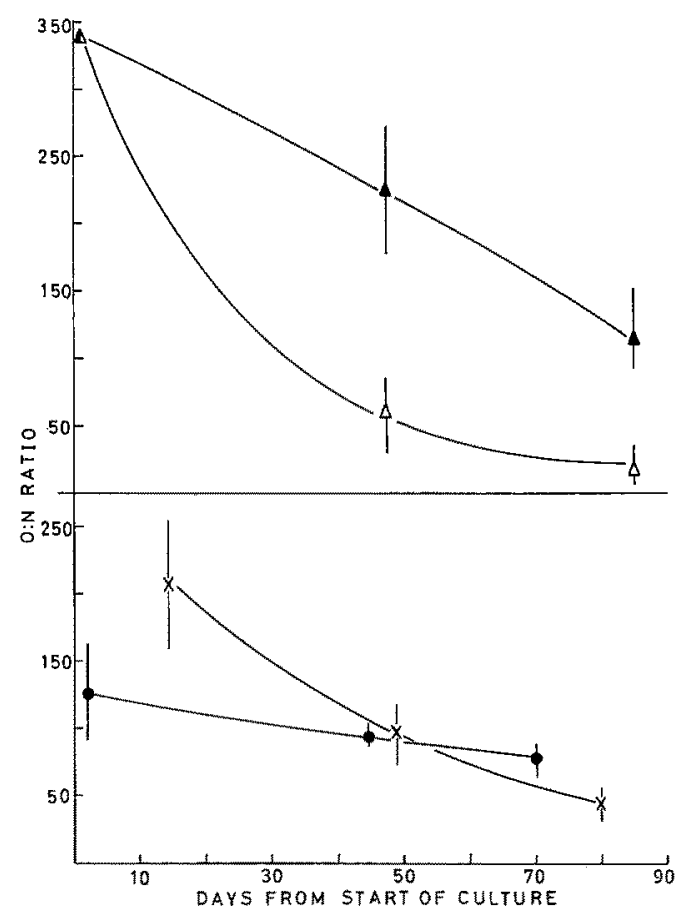

Fig. 15: Mytilus edulis. Ratio oxygen uptake: nitrogen excretion. Culture 1 (filled circles), culture 2 (crosses), culture 3 fed individuals (filled triangles), culture 3 unfed individuals (open triangles). Vertical bars indicate total ranges

By relating the observed rates of nitrogen excretion to the measured levels of protein in the animals, it is possible to compute a value for the "protein reserve"; that is, the maximum period for which $50 \%$ of the body proteins could last, in the absence of further food, if utilised at a constant rate. This calculation has been made for cultures 1,2 and 3 and the values are listed in Table 6. The seasonal difference is apparent, with high values in summer and autumn and low values in winter. The individuals in cultures 1 and 2 maintained a steady protein reserve (at least to the 40th day in culture 1), whereas in culture 3 there was an overall decline in the protein reserve in the fed individuals, and a marked reduction in the unfed animals.

For the second temperature experiment, animals were brought in from a field temperature of $10^{\circ} \mathrm{C}$ and held in the laboratory at $10^{\circ} \mathrm{C}$ and $20^{\circ} \mathrm{C}$. Oxygen consumption and nitrogen excretion rates were measured after 1, 15 and 50 days and are 
plotted, together with the $\mathrm{O}: \mathrm{N}$ ratios, in Figure 16. Nitrogen excretion rose at both temperatures, and $\mathrm{O}: \mathrm{N}$ ratios declined. Individuals exposed to the higher temperature responded with a greater utilisation of protein than did individuals at the lower temperature. This was apparent also in temperature experiment 1 , in which the protein reserve after 48 days at $16^{\circ} \mathrm{C}$ was less than $50 \%$ of the value at $6^{\circ} \mathrm{C}$.

Table 6

Mytilus edulis. The calculated 'protein reserve' for individuals in cultures 1, 2 and 3

\begin{tabular}{|c|c|c|c|c|}
\hline Culture & $\begin{array}{l}\text { Days from } \\
\text { start }\end{array}$ & $\begin{array}{l}\text { Excreted protein } \\
\text { (mg/animal/day) }\end{array}$ & $\begin{array}{l}\text { Body protein } \\
\text { (mg/animal) }\end{array}$ & $\begin{array}{l}\text { Protein } \\
\text { reserve } \\
\text { (days) }\end{array}$ \\
\hline Routine 1 & $\begin{array}{r}2 \\
44 \\
70\end{array}$ & $\begin{array}{l}0.14 \\
0.15 \\
0.13\end{array}$ & $\begin{array}{l}162 \\
162 \\
124\end{array}$ & $\begin{array}{l}562 \\
535 \\
462\end{array}$ \\
\hline Routine 2 & $\begin{array}{l}16 \\
45 \\
80\end{array}$ & $\begin{array}{l}0.74 \\
0.66 \\
0.58\end{array}$ & $\begin{array}{l}246 \\
232 \\
201\end{array}$ & $\begin{array}{l}166 \\
175 \\
173\end{array}$ \\
\hline $\begin{array}{l}\text { Routine } 3 \\
\text { fed } \\
\text { unfed }\end{array}$ & $\begin{array}{r}1 \\
43 \\
85 \\
1 \\
43 \\
85\end{array}$ & $\begin{array}{l}0.21 \\
0.23 \\
0.34 \\
0.21 \\
0.45 \\
0.71\end{array}$ & $\begin{array}{l}330 \\
211 \\
168 \\
330 \\
177 \\
119\end{array}$ & $\begin{array}{r}785 \\
460 \\
247 \\
785 \\
197 \\
84\end{array}$ \\
\hline
\end{tabular}

Summarising the data on metabolism and body reserves, it appears that for the first 40 days of culture 1 the carbohydrate reserves were utilised and the total protein maintained. After 40 days of culture, protein was more extensively utilised, the protein reserve of the body declined and the C:P ratio levelled out. In culture 2, carbohydrate was also extensively utilised for the first 40 days. The protein reserve was maintained, in spite of a declining $O: N$ ratio. After $40-50$ days, carbohydrate in non-mantle tissues increased, although mantle carbohydrate continued to be used. In cultures 1 and 2 approximately $30 \%$ of the total weight loss is not accounted for by loss of carbohydrate and protein (Table 4), and some of this may be due to loss of lipid.

In the fed individuals of culture 3 there was an extensive overall utilisation of both carbohydrate and protein. The protein reserve declined from a very high value, accompanied by a drop in the $\mathrm{O}: \mathrm{N}$ ratio. The pattern of change in the unfed animals of culture 3 was similar, but exaggerated. The low final $\mathrm{O}: \mathrm{N}$ values and the drastic decline in the protein reserve indicated a considerable protein utilisation in response to the nutritive stress.

The pattern of response to nutritive and temperature stress conditions was, therefore, somewhat similar in all the experiments. However, the results of both biochemical analyses and metabolic experiments show considerable seasonal differences in carbohydrate: protein balance and in main substrates utilised. This seasonal pattern is certainly related to seasonal changes in the gonad (DANIEL 1921, 1922) and possibly also to seasonal changes in the availability of food. 


\section{DISCUSSION}

In all these experiments, with the exception of the high-ration Mytilus edulis in the ration experiment, the food offered to the test individuals was not sufficient to meet the initial maintenance requirement. The maintenance requirement is assumed to be $1 \mathrm{mg}$ of organic matter/ml of oxygen consumed (JøRGENSEN 1966). Unpublished measurements of the rate of filtration of these animals suggest that a value
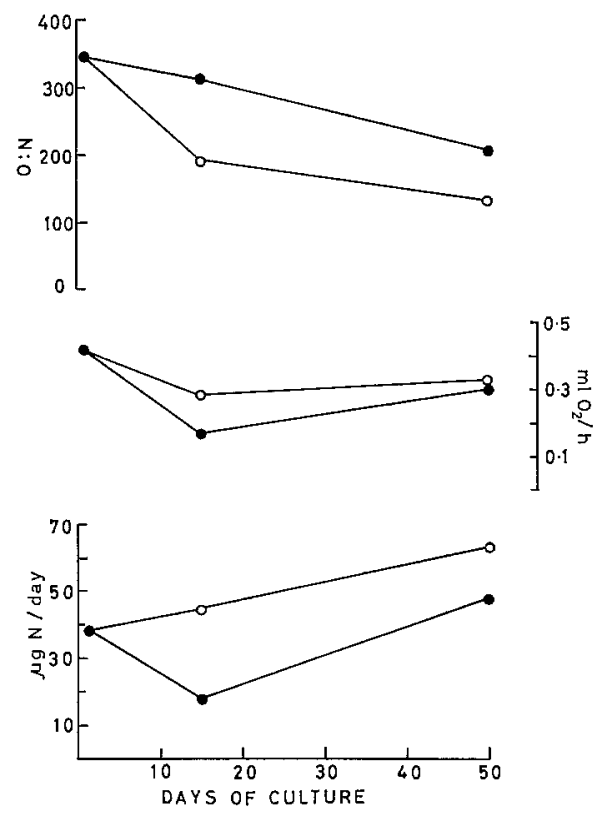

Fig. 16: Mytilus edulis. Temperature experiment 2. Ratio oxygen uptake: nitrogen excretion, oxygen consumption, and nitrogen excretion. $10^{\circ} \mathrm{C}$ : (filled circles), $20^{\circ} \mathrm{C}$ : (open circles)

of 1 litre of water filtered/h is representative; from the measured values of oxygen consumption it is possible to compute values for the volume of water pumped $/ \mathrm{ml}$ of oxygen consumed and, therefore, of the concentration of organic matter required to meet the maintenance requirement. These calculations assume a constant filtration rate during the course of each culture. We have no measurement of this, but other experiments do suggest that $M$. edulis can continue to filter at a constant rate over long periods in unfavourable circumstances. Calculations of maintenance requirement suggest that the individuals in culture 1 had an initial requirement 3.7 times higher than the food level; in culture 2 the requirement was 6.2 times the food level. The fed animals of culture 3 had an initial requirement 3.5 times, and the unfed animals 13.7 times, the measured food level. In all cultures depression of oxygen consumption eventually reduced the margin of difference between maintenance requirement and food level, but only after 60 days in culture $1 ; 75$ days in culture 2 and 80 days in culture 3 (fed) did the estimated maintenance requirement and the food level coincide. 
Shortage of food, therefore, represented a severe stressor in these experiments. Temperature represented another stress factor; as discussed earlier, the change from ambient sea temperature in the field to the temperature in the laboratory cultures was $2.5 \mathrm{C}^{0}$ for culture $1,10.0 \mathrm{C}^{0}$ for culture 2 and $5.0 \mathrm{C}^{0}$ for culture 3 . These assessments allow an approximate ranking of the three routine cultures in terms of the relative degree of nutritive and temperature stress, against which the changes in the measured physiological parameters may be judged. The ranking in order of intensity of stress is: culture 2, unfed individuals in culture 3 , fed individuals in culture 3 , and culture 1.

The condition index is descriptive of the effects of laboratory stress on Mytilus edulis. There were clear differences in this index between fed and unfed animals in culture 3, and also between individuals at different temperatures. The condition index declined in routine cultures, more so in culture 2 than in culture 1 . Other condition indices have been described (e. g. ANsell et al. 1964, BAIRd 1966, WALNE 1969) and proved useful. They are easily determined and, therefore, large samples are possible. More data are needed, however, on the relationship between such condition indices and the development of the gonad, and also on separate determinations of a condition index for mantle and non-mantle tissues.

The gonad index, as used in this paper, would not be suitable for describing an animal's response to stress, in view of the fact that it may be increased or maintained at the expense of other body tissues. However, a gonad index may be used, to some extent, to predict response to stress in terms of reproductive potential. There is a requirement here for more precise estimates of the maintenance requirement of Mytilus edulis in relation to the gonad index and to the sex of the animals.

Under conditions of stress, carbohydrate and protein reserves in the body were utilised in a sequence that resulted in a carbohydrate: protein ratio that declined over the first 20-40 days of culture, followed by a recovery to slightly higher values after 70-80 days. A considerable control of the carbohydrate: protein balance has been apparent in our results. In routine culture 3, the ration experiment and temperature experiment 1 , the similarity of $C: P$ ratios in animals maintained under very different conditions of ration and temperature was very close. Also, Mytilus edulis in culture in autumn and winter closely followed the natural seasonal pattern of change in the C:P ratio. Divergence from the natural pattern occurred in summer individuals which failed to spawn in the laboratory and so showed a C:P ratio lower than individuals in the field. The C:P ratio does not normally afford, therefore, a good description of the effects of stress.

The ratio oxygen consumed: nitrogen excreted (in so far as it gives some indication of the main substrates being oxidised by an animal) is a useful indicator of the individual's response to stress, especially as this can be determined without sacrificing the test animal. In cultures 1,2 and 3 the $\mathrm{O}: \mathrm{N}$ ratio declined in all cases; opposing the implied seasonal trend (Fig. 17), and the rate of decline was greatest in situations of maximum stress. The protein reserve, calculated from rates of nitrogen excretion and the measured total protein in the body, may also be used to describe an animal's response to stress. However, more data are needed concerning the relationship between the $O: N$ ratio and the respiratory quotient and regarding the effects of fat catabolism on the $\mathrm{O}: \mathrm{N}$ ratio. 
One possible explanation of the changing values for the $O: N$ ratio stems from the suggestion by HaMmEN (1968) that the razor clam Tagellus plebius may respond to stress by liberating more amino acids and less ammonia. If amino acid loss is a form of leakage, rather than true excretion (POTTS 1967), and the proportion of amino-nitrogen in the total 'excreted nitrogen' increases during stress, the decreasing $0: N$ values may not represent a true increase in protein metabolism. We are examining this possibility at present.

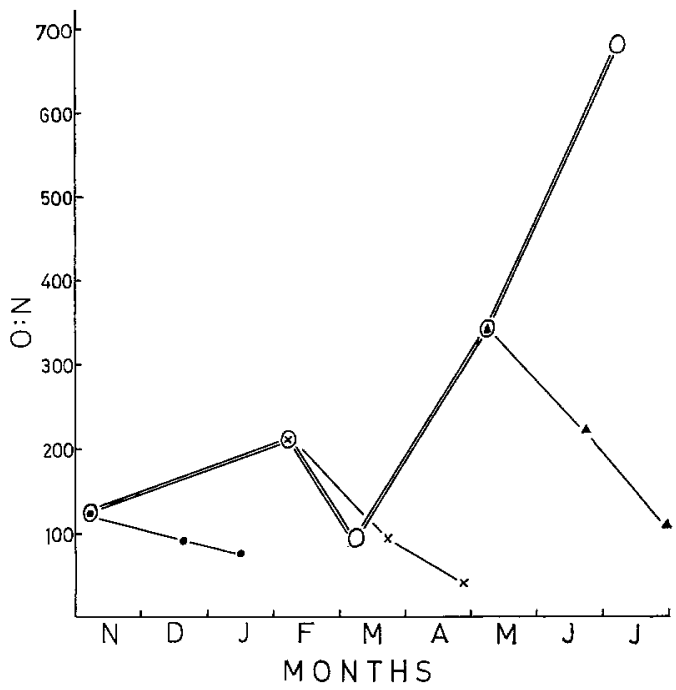

Fig. 17: Mytilus edulis. Ratio oxygen uptake: nitrogen excretion. Field sampled individuals (large open circles with double lines). Superimposed: culture 1 (filled circles), culture 2 (crosses), culture 3 fed individuals (filled triangles)

Three main points of interest emerge from these results. The first is the degree to which Mytilus edulis is able to isolate metabolic processes concerned with the production of gametes, from the processes of energy metabolism. In spite of considerable losses of carbohydrate and protein from both mantle and non-mantle tissues, individuals in autumn and winter were able to continue gamete maturation. Even in summer, if the food level was relatively high (ration experiment), the test animals were able to channel material from food and body reserves to maintenance of the gonad index.

The second point of interest relates to the degree of control shown by Mytilus edulis over the balance between carbohydrate and protein under different conditions of stress. The C:P ratio varies seasonally; however, perhaps not unexpectedly, a balance is kept between the utilisation of carbohydrate and protein undervery different conditions of ration and temperature. It would be interesting to know how seasonal and laboratory changes in body lipid might correlate with carbohydrate: protein balance (WALNE 1969).

The final point is the very marked seasonal variation in the patterns of meta- 
bolism in Mytilus edulis. A reliable picture of seasonal trends must be available before any physiological indices can be established as useful in describing the degree of stress experienced by $M$. edulis and before attempting to predict the mussel's response to known levels of stress. It is the degree to which the measured indices diverge from a basic seasonal pattern that will indicate how $M$. edulis is responding, or is likely to respond, to environmental stress. Of the parameters considered in this paper, it is possible to propose tentative schemes for seasonal changes in the following (using data from literature as well as some values of our own): the carbohydrate: protein ratio (WILliams 1969); the gonad index (ChIPPERFIEld 1953); a condition index (BAIRD 1966); and weight-specific oxygen consumption, reduced to constant temperature (BRUCE 1926, KRÜGER 1960). In addition, some seasonal data on the O:N ratio and relative values for the respiratory quotient (BRUCE 1926) are available. Some of these are plotted in Figure 18.

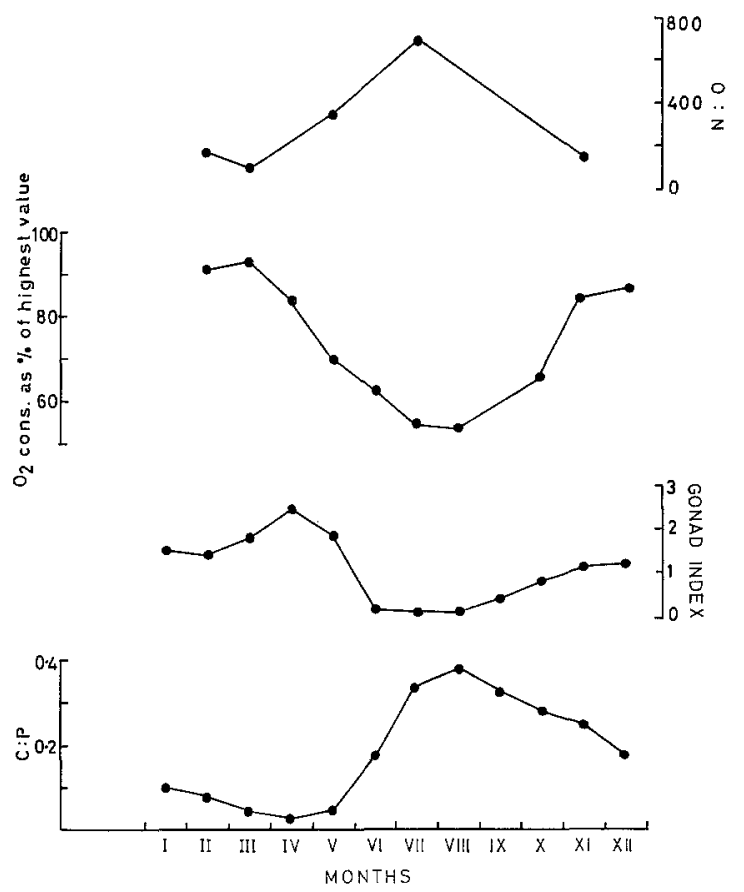

Fig. 18: Mytilus edulis. Seasonal trends in the ratio oxygen uptake: nitrogen excretion (present paper); in oxygen consumption as percentage of the seasonal maximum value (after BRUCE 1926 and present paper); in gonad index (after CHIPPERFIELD 1953); and in the ratio carbohydrate: protein (after WiLlIAMs 1969)

We interpret the seasonal pattern of metabolism as follows. As a result of spawning in spring or early summer, body protein and lipid decline sharply and the C:P ratio increases. General tissue metabolism is depressed; there is little metabolic activity in the gonad and body condition is low. During summer the rate of metabolism increases as carbohydrate reserves are laid down in the mantle; synthesis of carbo- 
hydrate and catabolism of fat result in a low respiratory quotient and high $\mathrm{O}: \mathrm{N}$ ratio at this time. The rate of metabolism continues to rise in autumn and early winter as body protein and lipid increase. There is an abundance of actively metabolising tissue in the mantle at this time; the $\mathrm{O}: \mathrm{N}$ ratio declines and the respiratory quotient increases as carbohydrate becomes the dominant substrate. The C:P ratio declines. In late winter and early spring protein and lipid reserves are increasingly laid down in the gametes and carbohydrates are catabolised. These reserves are not metabolically active, and this results in a decline in the rate of oxygen consumption. This decline in metabolic rate is continued at the time of spawning and reaches the low values recorded in midsummer. When such data can be established for different areas, and are shown to be consistent in time, they may serve as a basis for evaluating the degree of stress in natural and cultivated populations of Mytilus edulis.

\section{SUMMARY}

1. Nutritive and temperature stresses in experiments cause a decline in general body condition and dry weight of Mytilus edulis L. Carbohydrate and protein are lost from the body; these losses are greater from the germinal (mantle) than from the somatic (non-mantle) tissues. There is a more rapid loss of carbohydrate than of protein. $M$. edulis is able to maintain and continue maturation of the gametes in spite of this considerable utilisation of general body reserves.

2. The greater the degree of stress imposed on the test animals the greater is the utilisation of carbohydrate and protein. However, the mussels maintain a balance between these two components so that, at any one time, the carbohydrate to protein ratio does not differ between individuals subjected to different degrees of stress.

3. During the cultures there was a decline in oxygen consumption. Nitrogen excretion either increases or slightly decreases. The ratio oxygen consumed to nitrogen excreted declines in all experiments, indicating an increased use of protein as an energy substrate. The greater the degree of stress imposed upon the test animal, the greater the rate of decline of the $O: N$ ratio. The values for this ratio suggest that $M$. edulis normally utilises carbohydrate or fat substrates, though proteins may also be utilised in response to stress.

4. Indices of physiological condition should prove useful in determining the degrees of stress that are experienced by lamellibranchs under cultivation. In order to measure the effects of stress, knowledge of the normal seasonal variations in physiological indices is needed, to serve as a "base-line" with which induced changes in condition may be compared.

Acknoreledgements. We would like to thank Mrs. C. ORME for her very skilled assistance in carrying out many of the analyses. We also wish to thank Dr. P. WALNE for reading the manuscript. The research was supported by a Natural Environment Research Council grant No. GR/3/516 to B.L.B. and by a N.E.R.C. Studentship to R.J.T. 


\section{LITERATURE CITED}

Ansell, A. D., Loosmore, F. A., \& Lander, K. F., 1964. Studies on the hard shell clam, Venus mercenaria, in British waters. II. Seasonal cycle in condition and biochemical composition. J. appl. Ecol. 1, 83-95.

BAIRD, R. H., 1966. Factors affecting the growth and condition of mussels (Mytilus edulis L.). Fishery Invest., Lond. (Ser. 2) 25 (2), 1-33.

Barnes, H., Barnes, M., \& Finlayson, D. M., 1963. The metabolism during starvation of Balanus balanoides. J. mar. biol. Ass. U.K. 43, 213-223.

- \& Heath, J. R., 1966. The extraction of glycogen from marine invertebrate tissues. Helgoländer wiss. Meeresunters. 13, 115-117.

BAYNE, B. L., 1965. Growth and the delay of metamorphosis of the larvae of Mytilus edulis (L.). Ophelia 2, 1-47.

BRUCE, J. R., 1926. The respiratory exchange of the mussel (Mytilus edulis L.). Biochem. J. 20, 829-846.

Chipperfield, P. N. J., 1953. Observations on the breeding and settlement of Mytilus edulis (L.) in British waters. J. mar. biol. Ass. U.K. 32, 449-476.

CORNer, E. D. S., \& Cower, C. B., 1968. Biochemical studies on the production of marine zooplankton. Biol. Rev. 43, 393-426.

Daniel, R. J., 1921. Seasonal changes in the chemical composition of the mussel (Mytilus edulis), continued. Rep. Lancs. Sea-Fish. Labs 30, 205-221.

- 1922. Seasonal changes in the chemical composition of the mussel (Mytilus edulis), concluded. Rep. Lancs. Sea-Fish. Labs 31, 27-50.

Hammen, C. S., 1968. Amino transferase activities and amino acid excretion of bivalye molluscs and brachiopods. Comp. Biochem. Physiol. 26, 697-705.

Jørgensen, C. B., 1966. Biology of suspension feeding. Pergamon Press, Oxford, 357 pp.

KR ÜGER, F., 1960. Zur Frage der Größenabhängigkeit des Sauerstoffverbrauchs von Mytilus edulis L. Helgolünder wiss. Meeresunters. 7, 125-148.

Loosanoff, V. L., \& Davis, H. C., 1951. Delaying spawning of lamellibranchs by low temperature. J. mar. Res. 10, 197-202.

Lubet, P., 1955. Cycle neurosécrétoire chez Chlamys varia L. et Mytilus edulis L. (Mollusques Lamellibranches). C. r. hebd. Séanc. Acad. Sci., Paris, 241, 117-119.

Newell, B. S., 1967. The determination of ammonia in sea water. J. mar. biol. Ass. U.K. 47, 271-280.

Potтs, W. T. W., 1967. Excretion in the molluscs. Biol. Rev. 42, 1-41.

Price, C. A., 1965. A membrane method for determination of total protein in dilute algal suspensions. Analyt. Biochem. 12, 213-218.

Strickland, J. D. H., \& Parsons, T. R., 1960. A manual of sea water analysis. Bull. Fish. Res. Bd Can. 125, 1-185.

WALNE, P. R., 1969. The seasonal variation of meat and glycogen content of seven populations of oysters (Ostrea edulis L.) and a review of the literature. Fishery Invest., Lond. (Ser. 2) 26 (in press).

Williams, C. S., 1969. The effect of Mytilicola intestinalis on the biochemical composition of mussels. J. mar. biol. Ass. U.K. 49, 161-173.

First author's address: Dr. B. L. BAYNE

Department of Zoology

University of Leicester

Leicester, England 